\title{
Barbier-Negishi Coupling of Secondary Alkyl Bromides with Triflates and Nonaflates
}

\author{
Ke-Feng Zhang, Fadri Christoffel, and Olivier Baudoin*
}

\begin{abstract}
The development of a mild and practical Barbier-Negishi coupling of $2^{\circ}$ alkyl bromides with triflates and nonaflates is reported. This challenging reaction was enabled by a very bulky imidazole-based phosphine ligand, which allowed achieving good yields, chemo- and site-selectivities for a broad range of substrates at room temperature and under non-aqueous conditions. This reaction was extended to $1^{\circ}$ alkyl bromides by using an analogous pyrrazole-based ligand.
\end{abstract}

Secondary alkyl groups are important substructures found in various active pharmaceutical ingredients (APIs), such as the corticotropin-releasing factor $1\left(\mathrm{CRF}_{1}\right)$ antagonist $\mathbf{1},{ }^{[1]}$ and the anaplastic lymphoma kinase (ALK) inhibitor Ceritinib 2 (Figure 1a). ${ }^{[2]}$ The Negishi coupling of $2^{\circ}$ alkyl halides has proven a mild and efficient method to introduce these motifs (Figure 1b). ${ }^{[3]}$ However, a major limitation arises from the propensity of the corresponding $2^{\circ}$ alkylpalladium intermediate 7 to undergo migration and give rise to isomeric alkylpalladium complex $\mathbf{8}$ via $\beta$ hydride elimination, rotation of the Pd-alkene complex and alkene insertion, hence leading to a mixture of the ipso and cine products 4 and 5. In the last 30 years, various ligands and catalysts derived thereof have been developed to limit the migration pathway and favor the direct coupling product (Figure 1c), including diphosphines such as dpp $\mathrm{f}^{[4]}$ and bulky monodentate ligands such as tri-tert-butylphosphine, ${ }^{[5]}$ the biarylphosphine CPhos, ${ }^{[6]}$ and $\mathrm{N}$ heterocyclic carbenes. ${ }^{[7,8]}$ In all cases, the required $2^{\circ}$ organozinc halide 6 was preformed from the $2^{\circ}$ alkyl halide prior to the coupling step. On the other hand, Lipshutz and co-workers have reported Barbier-Negishi conditions allowing the cross-coupling of aryl and alkyl halides "on-water" or in water in the presence of a surfactant, and avoiding the preformation of the organozinc species. ${ }^{[9]}$ An improved catalytic system, allowing the crosscoupling of a range of cyclic alkyl bromides and (hetero)aryl electrophiles, has been recently disclosed by Buchwald and coworkers. ${ }^{[10]}$ However, Barbier-Negishi couplings under water-free conditions have remained elusive until recently. In 2016, Kishi and co-workers reported the development of one-pot conditions for the Fukuyama coupling leading to dialkylketones. ${ }^{[11,12]}$ In parallel, we reported the development of a migratory Barbier-Negishi crosscoupling operating in anhydrous THF and leading to linear products (Figure $1 \mathrm{~b}, \mathbf{5}$ with $\mathrm{R}^{1}=\mathrm{H}$ ) upon the use of a specifically designed phosphine ligand. ${ }^{[13]}$ Our initial efforts to extend this protocol to selectively obtain the valuable ipso product $\mathbf{4}$ using reported ligands were met with little success. We report herein the development of a new phosphine ligand $\mathbf{L}^{\mathbf{1}}$ (Figure 1c) enabling the cross-coupling of

[*] K.-F. Zhang, F. Christoffel, Prof. Dr. O. Baudoin University of Basel, Department of Chemistry, St. JohannsRing 19, CH-4056 Basel, Switzerland E-mail: olivier.baudoin@unibas.ch

Supporting information for this article is available on the WWW under http://www.angewandte.org or from the author. triflates and nonaflates with $2^{\circ}$ alkyl bromides under Barbier conditions with limited isomerization.

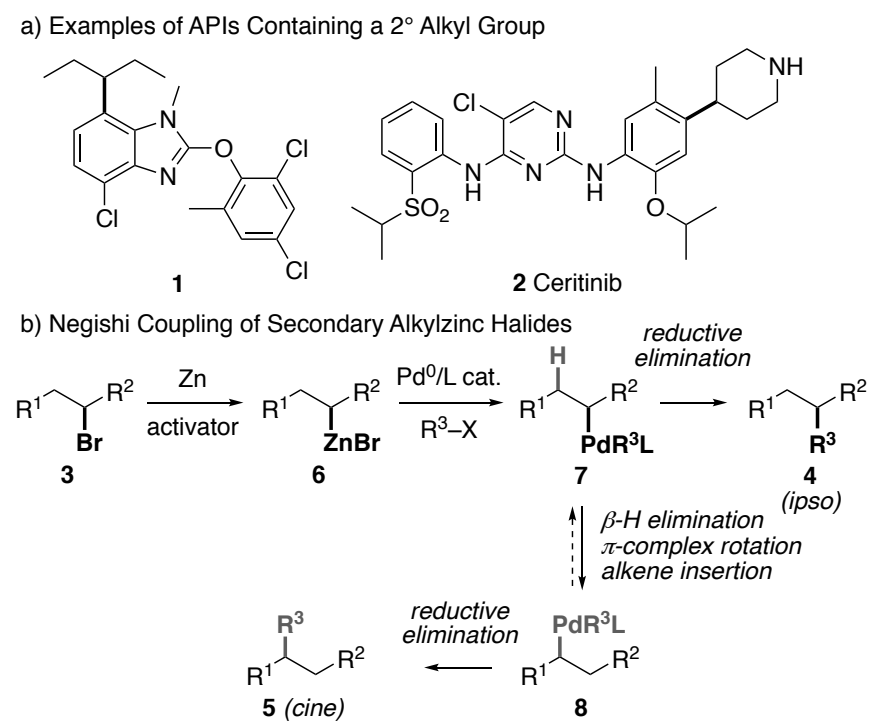

c) Examples of Branched-Selective Catalysts

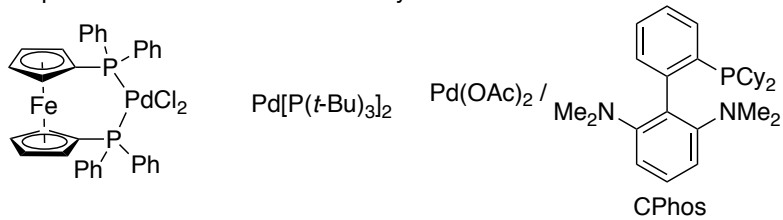

(Hayashi \& Higuchi, 1984) (Fu, 2001)

(Buchwald, 2009)

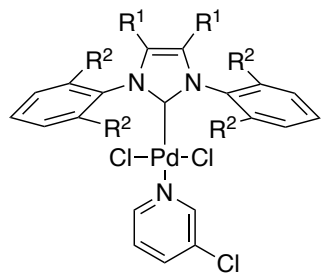

$\mathrm{R}^{1}=\mathrm{H}, \mathrm{Cl} ; \mathrm{R}^{2}=$ 3-pentyl, 4-heptyl

Pd-PEPPSI-IPent/Pent $/ / / \mathrm{Hept} / / \mathrm{Hept} \mathrm{Cl}$ • enhanced b/l selectivity (Organ, 2011-16)

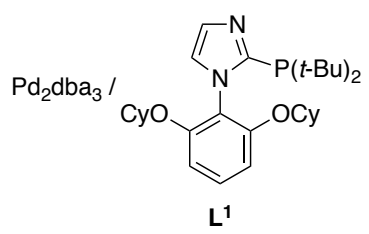

- compatible with Barbier conditions

Figure 1. Branched-selective Negishi coupling of $2^{\circ}$ alkyl halides.

We started to investigate the Barbier-Negishi coupling of aryl triflate 9a with 3-bromopentane 3a (Table 1). Previous studies showed the orthogonal character of these two coupling partner, with the alkyl bromide selectively undergoing magnesium insertion and transmetalation to zinc under Knochel's conditions, ${ }^{[14]}$ whereas the aryl triflate undergoes oxidative addition to the in situ-generated active palladium $(0)$ complex. ${ }^{[13 a]}$ We first examined commercially available ligands or catalysts derived thereof, which have been developed to perform branched-selective Negishi coupling (entries 1-9). ${ }^{[4-7]}$ Under Barbier conditions, only dppf and CPhos furnished a significant conversion of the aryl triflate, and CPhos provided a 
77:23 mixture of the ipso coupling product $4 \mathbf{a}$ and the $\mathrm{C}-2+\mathrm{C}-1$ isomers (entry 5). Control experiments performed with the corresponding preformed organozinc halide (entries 4, 6, 9) showed a restored reactivity and 84:16 selectivity for IPent, thereby pointing to the limited compatibility of Barbier conditions with existing Pd catalysts.

Table 1. Optimization of reaction conditions. ${ }^{[a]}$

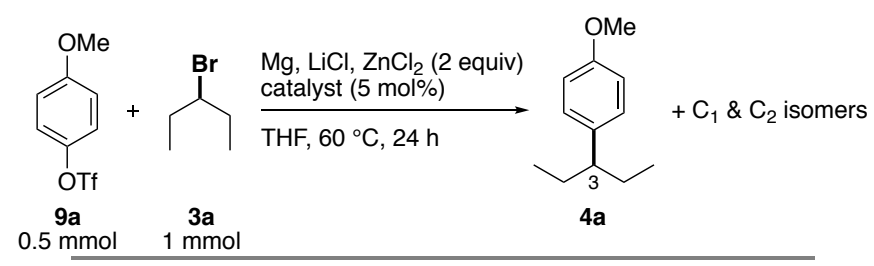

\begin{tabular}{|c|c|c|c|}
\hline Entry & Catalyst ${ }^{[a]}$ & Yield 4a [\% $]^{[b]}$ & Selectivity ${ }^{[c]}$ \\
\hline 1 & $\mathrm{PdCl}_{2}$ (dppf) & 39 & $56: 44$ \\
\hline 2 & $\mathrm{Pd}\left[\mathrm{P}(t-\mathrm{Bu})_{3}\right]_{2}$ & $<5$ & - \\
\hline 3 & {$\left[\mathrm{PdP}(t-\mathrm{Bu})_{3} \mathrm{Br}\right]_{2}$} & $<5$ & - \\
\hline $4^{[\mathrm{d}]}$ & $\mathrm{Pd}\left[\mathrm{P}(t-\mathrm{Bu})_{3}\right]_{2}$ & $<5$ & - \\
\hline 5 & $\mathrm{Pd}_{2} \mathrm{dba}_{3} / \mathrm{CPhos}$ & 71 & $77: 23$ \\
\hline $6^{[\mathrm{d}]}$ & $\mathrm{Pd}_{2} \mathrm{dba}_{3} / \mathrm{CPhos}$ & 75 & $76: 24$ \\
\hline 7 & Pd-PEPPSI-IPr & $<5$ & - \\
\hline 8 & Pd-PEPPSI-IPent & $<5$ & - \\
\hline $9^{[d]}$ & Pd-PEPPSI-IPent & 82 & $84: 16$ \\
\hline 10 & $\mathrm{Pd}_{2} \mathrm{dba}_{3} / \mathrm{L}^{2}$ & $<5$ & - \\
\hline 11 & $\mathrm{Pd}_{2} \mathrm{dba}_{3} / \mathrm{L}^{3}$ & 41 & $93: 7$ \\
\hline 12 & $\mathrm{Pd}_{2} \mathrm{dba}_{3} / \mathrm{L}^{4}$ & 20 & $64: 36$ \\
\hline 13 & $\mathrm{Pd}_{2} \mathrm{dba}_{3} / \mathrm{L}^{5}$ & 11 & $90: 10$ \\
\hline 14 & $\mathrm{Pd}_{2} \mathrm{dba}_{3} /$ RuPhos & 88 & $83: 17$ \\
\hline 15 & $\mathrm{Pd}_{2} \mathrm{dba}_{3} / \mathrm{L}^{6}$ & $<5$ & - \\
\hline 16 & $\mathrm{Pd}_{2} \mathrm{dba}_{3} / \mathrm{L}^{7}$ & 73 & $93: 7$ \\
\hline 17 & $\mathrm{Pd}_{2} \mathrm{dba}_{3} / \mathrm{L}^{8}$ & 61 & $94: 6$ \\
\hline 18 & $\mathrm{Pd}_{2} \mathrm{dba}_{3} / \mathrm{L}^{9}$ & 61 & $77: 23$ \\
\hline 19 & $\mathrm{Pd}_{2} \mathrm{dba}_{3} / \mathrm{L}^{10}$ & 18 & $81: 19$ \\
\hline 20 & $\mathrm{Pd}_{2} \mathrm{dba}_{3} / \mathrm{L}^{11}$ & 56 & $92: 8$ \\
\hline 21 & $\mathrm{Pd}_{2} \mathrm{dba}_{3} / \mathrm{L}^{1}$ & 83 & $93: 7$ \\
\hline $22^{[\mathrm{d}]}$ & $\mathrm{Pd}_{2} \mathrm{dba}_{3} / \mathrm{L}^{1}$ & 76 & $95: 5$ \\
\hline
\end{tabular}

[a] Well-defined catalyst $(5 \mathrm{~mol} \%)$ or $\mathrm{Pd}_{2} \mathrm{dba}_{3}(2.5 \mathrm{~mol} \%) /$ ligand $(5$ mol\%). [b] Determined by GC using dodecane as an internal standard. [c] GC ratios of $4 a /$ sum of C-1 and C-2 isomers. [d] Performed using the preformed organozinc halide under otherwise identical conditions.
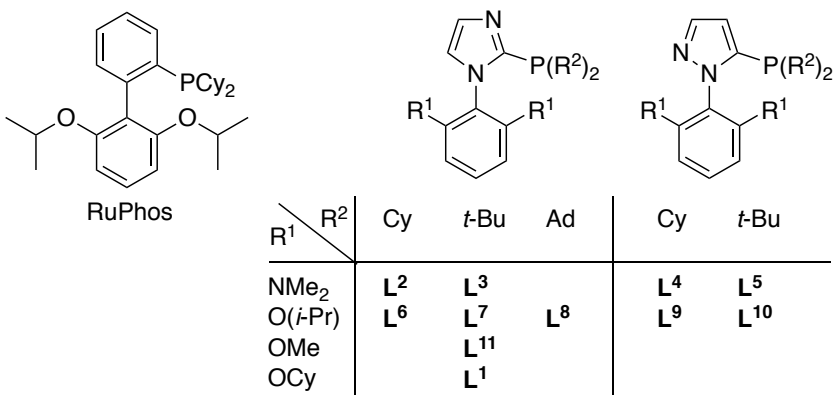

\begin{tabular}{ll|ll}
$t-\mathrm{Bu}$ & $\mathrm{Ad}$ & $\mathrm{Cy}$ & $t-\mathrm{Bu}$ \\
$\mathbf{L}^{3}$ & & $\mathbf{L}^{4}$ & $\mathbf{L}^{5}$ \\
$\mathbf{L}^{7}$ & $\mathbf{L}^{8}$ & $\mathbf{L}^{9}$ & $\mathbf{L}^{10}$ \\
$\mathbf{L}^{11}$ & & & \\
$\mathbf{L}^{1}$ & & &
\end{tabular}

After these first scouting experiments, we sought to synthesize new ligands which would both tolerate the Barbier conditions and allow improvement of the selectivity in favor of the direct coupling product 4a. Previous mechanistic studies indicated that increasing further the steric bulk at the phosphorus atom and the biaryl axis of the ligand should simultaneously decrease the energy barrier of the direct reductive elimination (Figure $1,7 \rightarrow 4$ ), and increase the barriers of the $\beta$-H elimination and $\pi$-complex rotation leading to $\mathrm{Pd}$ migration $(\mathbf{7} \rightarrow \mathbf{8})$, and hence should lead to improved selectivity for the direct coupling product. ${ }^{[15]} \mathrm{We}$ focused on the phenylazole family of ligands, which are readily synthesized by $\mathrm{Cu}$-catalyzed $\mathrm{C}$ $\mathrm{N}$ coupling and lithiation-phosphorylation, and wherein the steric and electronic properties can be easily modulated. ${ }^{[16,17]}$ CPhos analogues $\mathbf{L}^{\mathbf{2}}-\mathbf{L}^{\mathbf{5}}$ containing an imidazole or pyrrazole ring provided only a modest reactivity (entries 10-13), but the selectivity increased significantly when the $\mathrm{Cy}$ groups on the phosphorus atom were replaced with $t$-Bu groups $\left(\mathbf{L}^{3}, \mathbf{L}^{5}\right)$. Concomitantly, we found that RuPhos ${ }^{[18]}$ provided slightly enhanced yield and selectivity compared to CPhos (entries 5, 14). Hence, we synthesized and tested imidazole and pyrrazole analogues of RuPhos $\mathbf{L}^{6}-\mathbf{L}^{11}$ and $\mathbf{L}^{1}$ (entries 15-21). We concluded that: 1. tert-butyl substituents on the phosphine provide optimal reactivity and selectivity compared to cyclohexyl and adamantyl groups (entries 15-17); 2. the imidazole ring is superior to the more electron-deficient pyrrazole ring (entries 16 and 19); 3. cyclohexyloxy groups on the 2',6' positions provide higher yields than methoxy and isopropoxy groups (entries 16, 20, 21 ). A control experiment using $\mathbf{L}^{\mathbf{1}}$ and the preformed organozinc halide showed that this ligand performs equally well under both types of conditions (entries 21-22), and that it is more selective than previously developed ligands (entries 1-9).

Then, we further refined the reaction conditions using the optimized ligand $\mathbf{L}^{1}$, and gratifyingly we were able to decrease the excess of reagents required to form the organozinc intermediate from 2.0 to 1.5 equiv, the temperature from 60 to $25{ }^{\circ} \mathrm{C}$, and to replace the triflate leaving group with the less expensive nonaflate $^{[19,20]}$ (Scheme 1). Under these conditions, product 4a was obtained in $90 \%$ yield and with $94 \%$ selectivity. We next investigated the scope of the Barbier-Negishi coupling, starting with the electrophilic partner (Scheme 1a). The ratio ipso/mixture of isomers obtained with $\mathrm{CPhos}$ is given in some instances for comparison. Electron-donating and withdrawing groups at the para and meta positions of the aryl nonaflate were well tolerated (4a-k), including a chloride (4b) and a boronate (4d) which provide handles for further functionalization. The nonaflate bearing an ethyl ester was a notable exception, delivering the $\mathrm{C}-1$ isomer as the main product in low yield (see 4e). However, restored yield and ipso selectivity were observed in a control experiment with the preformed organozinc bromide (85:15), which further illustrates the differences between Negishi couplings performed under normal and Barbier conditions. Fortunately, replacing the nonaflate with triflate furnished a solution to this problem, and product $4 \mathbf{e}$ was obtained with a similar selectivity $(85: 15)$ to the normal Negishi coupling. The coupling of an aryl nonaflate bearing an ortho substituent (4I) represented another challenging case. Previous work showed that such groups tend to favor the migratory cross-coupling. ${ }^{[13 a]}$ Indeed, using CPhos as the ligand mainly led to isomerized products (41/isomers 36:64). Fortunately, ligand $\mathbf{L}^{\mathbf{1}}$ provided a reversed selectivity using both the nonaflate $(87: 13)$ and the triflate $(9: 1)$. The coupling of 2-pyridyl nonaflate also proved challenging, leading to product $\mathbf{4 m}$ with moderate selectivity (72:28), but isomerization mainly took place with CPhos (20:80). Other tested heteroaryl nonaflates provided a very good selectivity for the ipso product (4no). Moreover, cyclohexenyl nonaflates were suitable coupling partners, delivering products $\mathbf{4 p - q}$ with $>90 \%$ selectivity. Finally, a more complex estrone-derived nonaflate, containing an enolizable ketone, led to the direct cross-coupling product $\mathbf{4 r}$ in excellent yield and selectivity. 


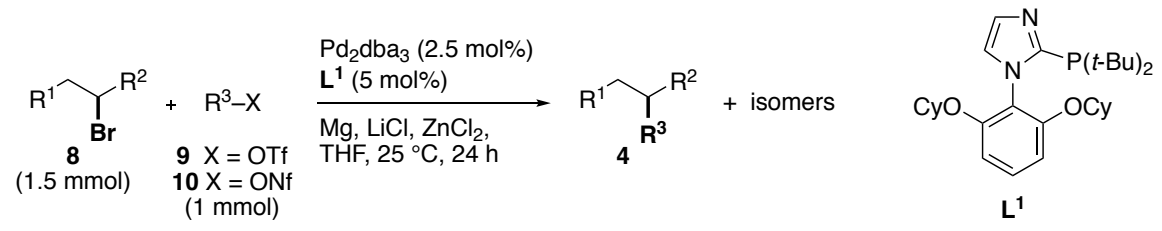

a) triflates and nonaflates

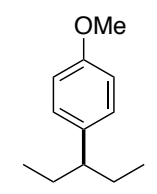

$4 a$

$\mathrm{X}=\mathrm{ONf}$

L': $90 \%, 94: 6$
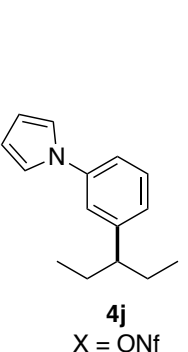

$\mathrm{X}=\mathrm{ONf}$

$L^{1}: 65 \%, 89: 11$

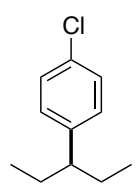

$4 b$

$\mathrm{X}=\mathrm{ONf}$

$L^{1}: 74 \%, 92: 8$

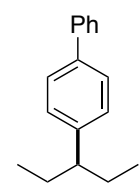

$4 c$
$\mathrm{X}=\mathrm{ONf}$

$X=0 N f$
$L^{1}: 86 \%, 93: 7$

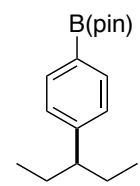

4d

$\mathrm{X}=\mathrm{OTf}$

$L^{1}: 64 \%, 98: 2$

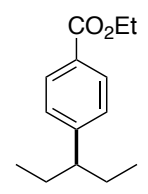

4 e $X=15 \%$, ONf $L^{1}: 10: 90$ $\mathrm{X}=\mathrm{OTf}$ $L^{1}:$ 74\%, 85:15

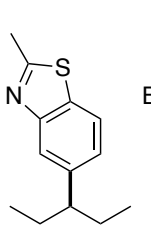

$\mathbf{4 k}$
$\mathrm{X}=\mathrm{OTf}$

$X=$ OTf
1: $64 \%, 93: 7$ $\begin{array}{cc}\mathbf{4 m} & \mathbf{4 n} \\ X=\text { ONf } & X=\text { ONf } \\ 1: 61 \%, 72: 28 & L^{1}: 68 \%, 94: 6\end{array}$

$\begin{array}{cc}\mathbf{4 m} & \mathbf{4 n} \\ X=\text { ONf } & X=\text { ONf } \\ 1: 61 \%, 72: 28 & L^{1}: 68 \%, 94: 6\end{array}$

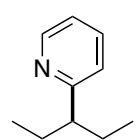

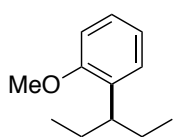

$\mathrm{X}=\mathrm{ONf}$ $L^{1}: 88 \%, 87: 13 \quad L^{1}: 61 \%, 72: 28$
CPhos: $36: 64 \quad$ CPhos: $20: 80$

$$
\mathrm{X}=\mathrm{OTf}
$$

$L^{1}: 79 \%, 90: 10^{[a]}$<smiles>CCC(CC)C(CC)c1cc(OC)c(OC)c(OC)c1</smiles><smiles>CCC(CC)c1ccc2c(c1)OCO2</smiles>

$4 f$

$\mathrm{X}=\mathrm{ONf}$

$L^{1}: 92 \%, 94: 6$

CPhos: 66:34

$\mathbf{4 g}$
$\mathrm{X}=\mathrm{ONf}$
$L^{1}: 81 \%, 94: 6$

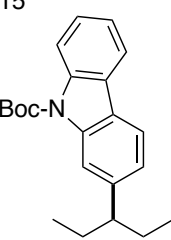

40

$X=$ OTf

$L^{1}: 96 \%, 99: 1$

CPhos: 71:29

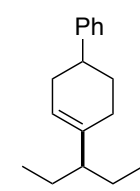

$4 \mathbf{p}$

$\mathrm{X}=\mathrm{ONf}$

$L^{1}: 62 \%, 93: 7$

CPhos: 83:17

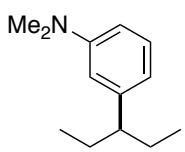

$\mathrm{F}_{3} \mathrm{C}$

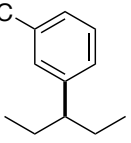

4h

$\mathrm{X}=\mathrm{ONf}$
$1: 84 \%, 94: 6$

$4 i$

$\mathrm{X}=\mathrm{ONf}$

$L^{1}: 62 \%, 91: 9$

CPhos: 70:30

$\mathrm{X}=\mathrm{OTf}$

$L^{1}:$ : $85 \%, 92: 8$

b) alkyl bromides ( $\mathrm{X}=\mathrm{ONf})$<smiles>COc1ccc(C(C)C)cc1</smiles><smiles>CCC(C)c1ccc(OC)cc1</smiles><smiles>COc1ccc(C(C)CC(C)C)cc1</smiles>

4u<smiles>COc1ccc(C(C)CCCC2(C)OCCO2)cc1</smiles><smiles>CCC(Cc1ccccc1)c1ccc(OC)cc1</smiles><smiles>CCC(CCC(C)=O)c1ccc(OC)cc1</smiles><smiles>CCC(CCC1OCCO1)c1ccc(OC)cc1</smiles>

$4 y$

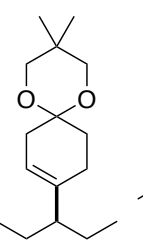

$4 \mathrm{q}$
$\mathrm{X}=\mathrm{ONf}$ $L^{1}: 55 \%, 94: 6$<smiles>CCC(CC)c1ccc2c(c1)CC[C@@H]1[C@@H]2CC[C@]2(C)C(=O)CC[C@@H]12</smiles>

$L^{1}:$ : 81\%, 98:2 CPhos: 78:22<smiles>[As][As]</smiles>

$L^{1}: 55 \%, 99: 1 \quad L^{1}: 62 \%,>99: 1 \quad L^{1}: 76 \%,>99: 1$

$4 \mathbf{v}$ CPhos: $98: 2$<smiles>CCC(CCC[OH2+])c1ccc(OC)cc1</smiles>

$L^{1}: 63 \%, 97: 3$<smiles>COc1ccc(C(C)CC(C)C)cc1</smiles>

$4 a b$

$L^{1}: 52 \%,>99: 1$ d.r. $60: 40$

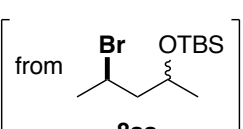

8 aa

Scheme 1. Scope and limitations of the Barbier-Negishi coupling of $2^{\circ}$ alkyl halides. Yields refer to the isolated mixture of cross-coupling products. [a] Using 2.0 equiv 3-bromopentane/Mg/LiCl, $\mathrm{ZnCl}_{2}$. [b] Using 2.0 equiv bromoalkane/ $\mathrm{Mg}^{\mathrm{L}} / \mathrm{LiCl}, \mathrm{ZnCl}, 5 \mathrm{~mol} \% \mathrm{Pd} \mathrm{dba}_{3}, 10 \mathrm{~mol} \% \mathrm{~L}{ }^{1}$, at $60{ }^{\circ} \mathrm{C}$. [c] Using 2.0 equiv bromoalkane/Mg/LiCl, ZnCl , at $40{ }^{\circ} \mathrm{C}$. [d] Using $1.25 \mathrm{~mol} \% \mathrm{Pd}_{2} \mathrm{dba}_{3}$ and $2.5 \mathrm{~mol} \% \mathrm{~L}^{1}$. $\mathrm{Tf}=\mathrm{CF}_{3} \mathrm{SO}{ }_{2} ; \mathrm{Nf}=$ $\mathrm{CF}_{3}\left(\mathrm{CF}_{2}\right)_{3} \mathrm{SO}_{2} ; \mathrm{Boc}=$ tert-butyloxycarbonyl; TBS = tert-butyldimethylsilyl.

This last case further illustrates the excellent functional group tolerance of this method, likely reflecting the fact that the transmetalation of the in situ-generated $2^{\circ}$ alkyl Grignard intermediate with $\mathrm{ZnCl}_{2}$ is faster than the enolate formation and nucleophilic addition on the ketone.

The scope in $2^{\circ}$ alkyl bromide was next investigated using 4methoxyphenyl nonaflate as the electrophile (Scheme 1b). Good yields and excellent selectivities were obtained for all tested $2^{\circ}$ alkyl bromides (4s-ac), regardless of the position of the bromine atom on the alkyl chain. Branching (4u), a phenyl group (4w) and a methyl ester (4x) were well tolerated, but aldehyde or ketone functions required protection as acetals $(\mathbf{4 v}, \mathbf{4 y})$ and a primary alcohol as a silyl ether (4aa). A Boc-protected $2^{\circ}$ amine was also tolerated (4z), but the reaction was sluggish and forcing conditions were necessary, presumably due to the coordinating ability of the Boc group. As expected, the reaction conducted from a 1:1 diastereoisomeric mixture of acyclic bromides 8aa led to arylated product $\mathbf{4 a b}$ with low 1,3-diastereoselectivity, ${ }^{[21]}$ and the same result was obtained with isolated syn and anti diastereoisomers of 8aa. Similarly, the coupling of an enantiopure alkyl bromide furnished a racemic product. ${ }^{[22]}$ In contrast, the reaction of the menthol-derived cyclic bromide 8ab occurred with excellent diastereoselectivity to give compound 4ac wherein the isopropyl and aryl groups are trans and equatorial, in agreement with the work of Knochel and coworkers. ${ }^{[23]}$ Finally, we successfully scaled up the reaction to 10 mmol of aryl nonaflate, leading to $2.2 \mathrm{~g}$ of the arylated product 4 ad in $75 \%$ yield at $25^{\circ} \mathrm{C}$ and under reduced catalyst loading $(2.5 \mathrm{~mol} \%$ $\left.\operatorname{Pd} / \mathbf{L}^{1}\right)$. 
In addition, we sought to extend this Barbier-Negishi coupling to $1^{\circ}$ alkyl bromides (Scheme 2). Surprisingly, the reaction of 1 bromopentane 11c with aryl nonaflate 10a in the presence of the same ligand as above $\left(\mathbf{L}^{\mathbf{1}}\right)$ was inefficient, leading mainly to the homocoupling of 10a. Fortunately, after a brief screen of other azole-based ligands, ${ }^{[22]}$ we found that less electron-rich pyrrazolebased phosphines afforded a solution to this problem. In particular, using $\mathbf{L}^{9}$ as the ligand allowed performing the Barbier-Negishi coupling of $1^{\circ}$ alkyl bromides 11a-d with nonaflate 10a in excellent yields (Scheme 2).

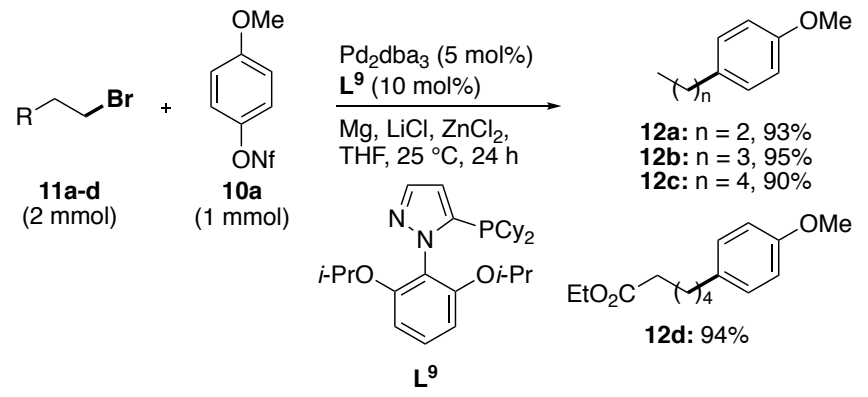

Scheme 2. Barbier-Negishi coupling of $1^{\circ}$ alkyl halides.

In conclusion, we reported the development of the BarbierNegishi coupling of $2^{\circ}$ alkyl bromides with (hetero)aryl triflates and nonaflates under mild, non-aqueous conditions. The use of a very bulky imidazole-based phosphine ligand allowed achieving good yields, chemo- and site-selectivities for a broad range of substrates. This practical reaction was extended to $1^{\circ}$ alkyl bromides by using an analogous, pyrrazole-based ligand.

Received: ((will be filled in by the editorial staff))

Published online on ((will be filled in by the editorial staff))

\section{Acknowledgments}

This work was financially supported by the China Scholarship Council (201406250018), the Swiss National Science Foundation (200021 165987) and the University of Basel. We thank Dr. D. Häussinger for NMR experiments, S. Mittelheisser and Dr. H. Nadig for MS analyses, Dr. J. Rotzler, Dr. J. Schranck (Solvias AG) and Dr. Fabrice Gallou (Novartis) for helpful discussions.

Keywords: cross-coupling $\cdot$ palladium $\cdot$ synthetic methods

[1] Y. Sawai, O. Yabe, K. Nakaoka, T. Ikemoto, Org. Process Res. Dev. 2017, 21, 222-230.

[2] T. H. Marsilje, W. Pei, B. Chen, W. Lu, T. Uno, Y. Jin, T. Jiang, S. Kim, N. Li, M. Warmuth, Y. Sarkisova, F. Sun, A. Steffy, A. C. Pferdekamper, A. G. Li, S. B. Joseph, Y. Kim, B. Liu, T. Tuntland, X. Cui, N. S. Gray, R. Steensma, Y. Wan, J. Jiang, G. Chopiuk, J. Li, W. P. Gordon, W. Richmond, K. Johnson, J. Chang, T. Groessl, Y.-Q. He, A. Phimister, A. Aycinena, C. C. Lee, B. Bursulaya, D. S. Karanewsky, H. M. Seidel, J. L. Harris, J. L.; P.-Y. Michellys, J. Med. Chem. 2013, 56, 5675-5690.

[3] D. Haas, J. M. Hammann, R. Greiner, P. Knochel, ACS Catal. 2016, 6, 1540-1552.

[4] T. Hayashi, M. Konishi, Y. Kobori, M. Kumada, T. Higuchi, K. Hirotsu, J. Am. Chem. Soc. 1984, 106, 158-163.
[5] a) C. Dai, G. C. Fu, J. Am. Chem. Soc. 2001, 123, 2719-2724; b) I. Kalvet, T. Sperger, T. Scattolin, G. Magnin, F. Schoenebeck, Angew. Chem. Int. Ed. 2017, 56, 7078-7082.

[6] a) C. Han, S. L. Buchwald, J. Am. Chem. Soc. 2009, 131, 7532-7533; b) Y. Yang, K. Niedermann, C. Han, S. L. Buchwald, Org. Lett. 2014, 16, 4638-4641.

[7] a) S. Çalimsiz, M. G. Organ, Chem. Commun. 2011, 47, 5181-5183; b) M. Pompeo, R. D. J. Froese, N. Hadei, M. G. Organ, Angew. Chem. Int. Ed. 2012, 51, 11354-11357; c) B. Atwater, N. Chandrasoma, D. Mitchell, M. J. Rodriguez, M. Pompeo, R. D. J. Froese, M. G. Organ, Angew. Chem. Int. Ed. 2015, 54, 9502-9506; d) B. Atwater, N. Chandrasoma, D. Mitchell, M. J. Rodriguez, M. G. Organ, Chem. Eur. J. 2016, 22, 14531-14534.

[8] An alternative approach consists of using first row transition-metals such as nickel, adopting oxidation degrees at which $\beta-\mathrm{H}$ elimination is disfavored. See for instance: a) J. C. Tellis, C. B. Kelly, D. N. Primer, M. Jouffroy, N. R. Patel, G. A. Molander, Acc. Chem. Res. 2016, 49, 1429-1439; b) J. Choi, G. Fu, Science 2017, 356, eaaf7230.

[9] a) A. Krasovskiy, C. Duplais, B. H. Lipshutz, J. Am. Chem. Soc. 2009, 131,15592-15593; b) C. Duplais, A. Krasovskiy, A. Wattenberg, B. H. Lipshutz, Chem. Commun. 2010, 46, 562-564; c) A. Krasovskiy, C. Duplais, B. H. Lipshutz, Org. Lett. 2010, 12, 4742-4744; d) V. Krasovskaya, A. Krasovskiy, B. H. Lipshutz, Chem. Asian J. 2011, 6, 1974-1976.

[10] V. R. Bhonde, B. T. O'Neill, S. L. Buchwald, Angew. Chem. Int. Ed. 2016, 55, 1849-1853.

[11] J. H. Lee, Y. Kishi, J. Am. Chem. Soc. 2016, 138, 7178-7186.

[12] For the cross-coupling of aryl bromides with aryl triflates using a NiPd bicatalytic system and stoichiometric $\mathrm{Zn}$, employed as a reductant to regenerate the active $\mathrm{Ni}^{0}$ species: L. K. G. Ackerman, M. M. Lovell, D. J. Weix, Nature 2015, 524, 454-457; b) for the synthesis of biaryls by homo- or cross-coupling via the in situ generation of a aryllithium intermediate: E. B. Pinxterhuis, P. Visser, I. Esser, J.-B. Gualtierotti, B. L. Feringa, Angew. Chem. Int. Ed. doi: 10.1002/anie.201707760.

[13] a) S. Dupuy, K.-F. Zhang, A.-S. Goutierre, O. Baudoin, Angew. Chem. Int. Ed. 2016, 55, 14793-14797; b) For an account on migratory crosscouplings: O. Baudoin, Chimia 2016, 70, 768-772.

[14] T. D. Blümke, F. M. Piller, P. Knochel, Chem. Commun. 2010, 46, 4082-4084.

[15] A. Millet, D. Dailler, P. Larini, O. Baudoin, Angew. Chem. Int. Ed. 2014, 53, 2678-2682.

[16] a) A. Zapf, R. Jackstell, F. Rataboul, T. Riermeier, A. Monsees, C. Fuhrmann, N. Shaikh, U. Dingerdissen, M. Beller, Chem. Commun. 2004, 38-39; b) F. Rataboul, A. Zapf, R. Jackstell, S. Harkal, T. Riermeier, A. Monsees, U. Dingerdissen, M. Beller, Chem. Eur. J. 2004, 10, 2983-2990; c) T. Schulz, C. Torborg, B. Schäffner, J. Huang, A. Zapf, R. Kadyrov, A. Börner, M. Beller, Angew. Chem. Int. Ed. 2009, 48, 918-921.

[17] a) S. Aspin, A.-S. Goutierre, P. Larini, R. Jazzar, O. Baudoin, Angew. Chem. Int. Ed. 2012, 51, 10808-10811; b) S. Aspin, L. López-Suárez, P. Larini, A.-S. Goutierre, R. Jazzar, O. Baudoin, Org. Lett. 2013, 15, 5056-5059; c) A. Millet, P. Larini, E. Clot, O. Baudoin, Chem. Sci. 2013, 4, 2241-2247.

[18] J. E. Milne, S. L. Buchwald, J. Am. Chem. Soc. 2004, 126, 1302813032.

[19] $\mathrm{CF}_{3}\left(\mathrm{CF}_{2}\right)_{3} \mathrm{SO}_{2} \mathrm{~F}$ is $1.3-2.2 \times$ less expensive (per mol) than $\left(\mathrm{CF}_{3} \mathrm{SO}_{2}\right)_{2} \mathrm{O}$.

[20] a) M. Rottländer, P. Knochel, J. Org. Chem. 1998, 63, 203-208; for a review: b) J. Högermeier, H.-U. Reissig, Adv. Synth. Catal. 2009, 351, $2747-2763$

[21] S. Tang, S.-H. Li, D. Zhou, H.-Q. Zeng, N.-X. Wang, Sci. China Chem. 2013, 56, 1293-1300.

[22] See the Supporting Information for details.

[23] T. Thaler, B. Haag, A. Gavryushin, K. Schober, E. Hartmann, R. M. Gschwind, H. Zipse, P. Mayer, P. Knochel, Nat. Chem. 2010, 2, 125130. 


\section{C-C Coupling}

K.-F. Zhang, F. Christoffel, O.

Baudoin*

Page - Page

Barbier-Negishi Coupling of Secondary

Alkyl Bromides with Triflates and

Nonaflates

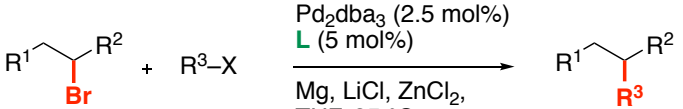

$$
\begin{aligned}
& \mathrm{X}=\mathrm{OTf} \quad \mathrm{THF}, 25^{\circ} \mathrm{C} \quad \cdot 30 \text { examples } \\
& \text { or ONf } \quad \text { - chemoselective } \\
& \text { - limited isomerization } \\
& \text { COCyO } \\
& \text { - applicable to } 1^{\text {ary }} \text { alkyl bromides }
\end{aligned}
$$

Simple and mild: the Barbier-Negishi coupling of $2^{\circ}$ alkyl bromides with triflates and nonaflates was performed at room temperature with good chemoselectivity and limited isomerization in the presence of a very bulky phosphine ligand. 